Article

\title{
Solvent-Free Mizoroki-Heck Reaction Applied to the Synthesis of Abscisic Acid and Some Derivatives
}

\author{
Geoffrey Dumonteil ${ }^{(D)}$, Marie-Aude Hiebel ${ }^{(D)}$ and Sabine Berteina-Raboin * \\ Institut de Chimie Organique et Analytique (ICOA), Université d'Orléans UMR CNRS 7311, BP 6759, \\ rue de Chartres, 45067 Orleans CEDEX 2, France; Geoffrey.Dumonteil@sanofi.com (G.D.); \\ marie-aude.hiebel@univ-orleans.fr (M.-A.H.) \\ * Correspondence: sabine.berteina-raboin@univ-orleans.fr; Tel.: +33-238-494-856
}

Received: 28 February 2018; Accepted: 13 March 2018; Published: 15 March 2018

\begin{abstract}
Abscisic acid (ABA) is a natural product, which is a well-known phytohormone. However, this molecule has recently exhibited interesting biological activities, emphasizing the need for a simple and direct access to new analogues based on the ABA framework. Our strategy relies on a pallado-catalyzed Mizoroki-Heck cross-coupling as key reaction performed in solvent and ligand free conditions. After a careful optimization, we succeeded in accessing various $(E / Z)$-dienes and $(E / E / Z)$-trienes in moderate to good yields without isomerization and applied the same approach to the synthesis of ABA in an environmentally sound manner.
\end{abstract}

Keywords: Mizoroki-Heck; abscisic acid; solvent-free

\section{Introduction}

Polyenic scaffolds constitute an important functionality among organic compounds and have a high synthetic interest since medicinally relevant molecules and natural products exhibit diene fragments (Figure 1) [1].

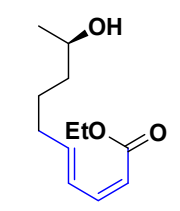

Modiolin<smiles>CC1=CC(=O)CC(C)(C)[C@@]1(O)/C=C/C(C)=C/C(=O)O</smiles>

Abscisic acid<smiles>COC(C/C=C/C=C(\C)C(=O)O)CC/C=C/CCCC(C)O</smiles>

Dolatrienic acid<smiles>CC(/C=C/C(=O)NO)=C\C(C)C(=O)c1ccc(N(C)C)cc1</smiles>

Trichostatin A

Figure 1. Examples of biologically active natural products containing diene moieties.

Several synthetic methods have therefore been developed to obtain these carotenoid moieties in iterative process or in convergent methods [2]. Traditionally, the olefination reaction was extensively used. However, it is often associated with the uncontrolled production of $\mathrm{E}$ and $\mathrm{Z}$ isomers which may require careful purification [3]. Then transition metal-catalyzed cross-coupling reactions galvanized the synthesis of these complex conjugated molecules. Catalysts such as ruthenium [4], zirconium [5-7], zinc [8] and nickel [9] were successfully used. The use of palladium has been widely reported with 
Negishi [10,11], Stille [12-15], Suzuki-Miyaura [16-18], Sonogashira [19], Kumada-Tamao [20] and Mizoroki-Heck [21-25] cross-coupling reactions [26-28]. Lately, the use of single unsaturated units as building blocks was promoted to respond to the challenging but crucial control of the configuration of the double bond generated [29-33]. In our effort to develop environmentally benign tools [34-36], we herein report the use of the Mizoroki-Heck reaction, which requires simple and directly accessible starting materials to build stereocontrolled dienes and trienes. Unlike other cross-coupling approaches, which may require several steps to install the pre-activated partners, the Mizoroki-Heck reaction enables the direct formation of dienes from terminal olefin substrates. The efficiency of our method was then evaluated in the synthesis of abscisic acid, an important phytohormone [37-43] which has been recently reported to have interesting biological effects $[44,45]$.

\section{Results and Discussion}

\subsection{Optimization of the Mizoroki-Heck Reaction}

To achieve the optimized conditions, the cross-coupling reaction of 1-ethenyl-3-methylcyclohex-2en-1-ol $\underline{\mathbf{1}}$ with methyl (2Z)-3-iodobut-2-enoate $\underline{\mathbf{2}}$ was selected as the model reaction under the standard conditions previously described by Cossy and co-workers (Table 1, entry 1) [46]. Surprisingly, only degradation was observed. Since conjugated products are prompted to make versatile rearrangement $[47,48]$, the reaction was next performed in a flask protected from natural light. A small amount of the expected product $\underline{3} \mathbf{a}$ was isolated along with the side product $\underline{4}$ (entry 2 ). The formation of $\underline{4}$ can be explained by a 1,3-rearrangement of the allylic alcohol, a transformation previously described by $\mathrm{Qu}$ and co-workers under a thermal activation in water [48]. The use of acetonitrile moreover of an additional ligand induced no positive change (entries 3 and 4) [49]. However, a significant improvement was obtained by replacing silver acetate by silver carbonate and 1.5 equiv. of silver carbonate proved to be the optimized amount (entries 5-7). A moderate heating is recommended since the formation of $\underline{\mathbf{3 a}}$ was significantly reduced at $80^{\circ} \mathrm{C}$.

Table 1. Optimization of the Mizoroki-Heck reaction between $\underline{\mathbf{1}}$ and $\underline{\mathbf{2}}$.

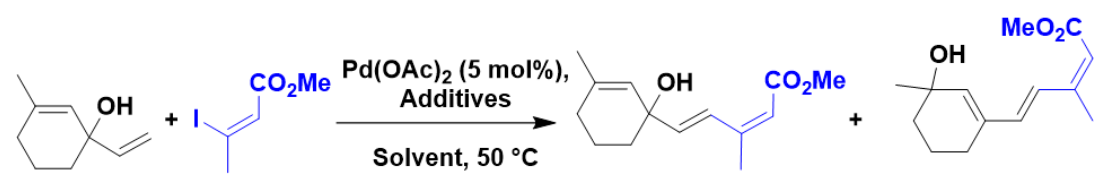

1

$\underline{2}$

$\underline{3 a}$

$\underline{4}$

\begin{tabular}{|c|c|c|c|c|c|c|}
\hline Entry & $\stackrel{1}{1}$ & $\stackrel{2}{\stackrel{2}{\text { (equiv.) }}}$ & $\begin{array}{l}\text { Additive } \\
\text { (equiv.) }\end{array}$ & Solvent & $\begin{array}{c}\text { Time } \\
\text { (h) }\end{array}$ & $\begin{array}{c}\text { Yield } \\
\underline{3}: \underline{4}(\%)\end{array}$ \\
\hline 1 & 1.2 & 1 & AgOAc (1.1) & DMF & 17 & $0: 0^{a}$ \\
\hline 2 & 1.2 & 1 & $\mathrm{AgOAc}(1.1)$ & DMF & 17 & $5: 4^{b}$ \\
\hline 3 & 1.2 & 1 & AgOAc (1.1) & $\mathrm{MeCN}$ & 17 & $9: 0^{b}$ \\
\hline 4 & 1.2 & 1 & $\begin{array}{l}\mathrm{AgOAc}(1.1) \\
P(o \mathrm{Tol})_{3}(0.1)\end{array}$ & $\mathrm{MeCN}$ & 17 & $9: 20^{b}$ \\
\hline 5 & 1.2 & 1 & $\mathrm{Ag}_{2} \mathrm{CO}_{3}(1.5)$ & $\mathrm{MeCN}$ & 17 & $63: 0^{b, c}$ \\
\hline 6 & 1.2 & 1 & $\mathrm{Ag}_{2} \mathrm{CO}_{3}(2)$ & $\mathrm{MeCN}$ & 17 & $63: 0^{b, c}$ \\
\hline 7 & 1.2 & 1 & $\mathrm{Ag}_{2} \mathrm{CO}_{3}(1.1)$ & $\mathrm{MeCN}$ & 17 & $54: 0^{b, c}$ \\
\hline 8 & 1.2 & 1 & $\mathrm{Ag}_{2} \mathrm{CO}_{3}(1.5)$ & $\mathrm{MeCN}$ & 17 & $10: 0^{b, c, d}$ \\
\hline 9 & 1.2 & 1 & $\mathrm{Ag}_{2} \mathrm{CO}_{3}(1.5)$ & none & 1 & $63: 0^{b, c}$ \\
\hline 10 & 1 & 2 & $\mathrm{Ag}_{2} \mathrm{CO}_{3}(1.5)$ & none & 1 & $60: 0^{b, c}$ \\
\hline 11 & 1 & $1+1$ & $\mathrm{Ag}_{2} \mathrm{CO}_{3}(1.5)$ & none & 1 & $50: 0^{b, c}$ \\
\hline 12 & 1.2 & 1 & $\mathrm{Ag}_{2} \mathrm{CO}_{3}(1.5)$ & none & 1 & $62: 0^{b, d}$ \\
\hline
\end{tabular}

${ }^{a}$ The reaction was performed under natural light. ${ }^{b}$ Reaction performed protected from natural light. ${ }^{c}$ Reaction performed under air. ${ }^{d}$ The reaction temperature was set at $80^{\circ} \mathrm{C} .{ }^{e}$ Reaction performed under inert atmosphere.

Next, neat conditions were tried, and even if the reaction mixture was a thick paste, the expected product $\underline{3 a}$ was isolated in similar yield $(63 \%)$ in a considerably shorter time ( $1 \mathrm{~h}$ vs. $17 \mathrm{~h})$. To the best 
of our knowledge, this is the first example of neat Mizoroki-Heck reaction for the formation of dienes. The vinylation of acrylic substrates has been already reported in solvent-free conditions but it usually requires the use of a ligand, palladium supported catalyst, palladium nanocatalyst or microwave activation [50-57]. Finally, $\underline{\mathbf{2}}$ was introduced in excess, in one portion or in sequential addition, without improving the yield (entries 10 and 11). Hence the optimized reaction conditions were as follows: in a flask protected from light, $\underline{\mathbf{1}}$ (1.2 equiv.) and $\underline{\mathbf{2}}$ (1 equiv.) in presence of $\mathrm{Pd}(\mathrm{OAc})_{2}(5 \mathrm{~mol} \%)$ and $\mathrm{Ag}_{2} \mathrm{CO}_{3}$ (1.5 equiv.) at $50{ }^{\circ} \mathrm{C}$ for $1 \mathrm{~h}$. It should be noted that working under an inert atmosphere did not improve the yield of the products $\underline{3 a}$ and $\underline{4}$ (entry 12 ).

\subsection{Substrate Scope}

A diversity of terminal olefin substrates was tested in the coupling reaction with methyl (2Z)-3-iodobut-2-enoate $\mathbf{2}$. The results are reported in Scheme 1. Various allylic cyclohexenols and cyclohexanols were examined and the expected dienes were obtained in moderate to good yields $\underline{\mathbf{3 a}} \underline{\underline{\mathbf{z}}} \mathbf{f}$. The presence of an unsaturation and/or different methyl substituents on the ring had little influence on the efficiency of the reaction. The variation of the yield observed was more substrate-dependent since $\underline{\mathbf{3 c}}$ and $\underline{\mathbf{3 d}}$ appeared to be very unstable and degraded spontaneously if not stored at low temperature in dark conditions. For these compounds, the reaction was tried at room temperature; however, the cross-coupling reaction failed completely. The stability issue was even more pronounced for 1-ethenylcyclopentan-1-ol, since its formation from cyclopentanone was difficult. The cross-coupling reaction was performed on the crude starting material, which could explain the low yield observed. Surprisingly, the resulting product $\mathbf{3 g}$ was completely bench stable. Satisfyingly, sterically hindered secondary alcohols $\underline{3} \mathbf{h}$ and sensitive tertiary alcohols $(\underline{\mathbf{3 a}}-\mathbf{3 g})$ were well tolerated under our optimized conditions. Even the volatile ethenylcyclohexane, which required working in a sealed tube, and the unstable styrene led to the corresponding dienes $\mathbf{3} \mathbf{i}$ and $\mathbf{3} \mathbf{j}$ in $42 \%$ and $78 \%$ yields. It is worth noting that all the coupling products were obtained as pure $(E, Z)$-dienes. The configuration of the diene was confirmed by ${ }^{1} \mathrm{H}$ NMR (Supplementary Materials: Figure S1). The chemical shift of the hydrogen alpha to the ester moiety is in accordance with the values reported in the literature for a $(E / Z)$-diene, around 5.5 ppm (vs. 6.0 ppm for a $E / E$ fragment) [58].

Finally, different vinylic iodides were submitted to our solvent-free Mizoroki-Heck conditions. (2Z)-3-iodobut-2- enenitrile $\underline{\mathbf{2 a}}$, Methyl (2Z)-3-iodoacrylate $\underline{\mathbf{2 b}}$, and 4-nitrophenyl(2Z)-3-iodobut-2-enoate $\underline{\mathbf{2 c}}$ were successfully introduced on 1-ethenyl-3-methylcyclohex-2-en-1-ol $\underline{1}$ leading to expected compounds $(\underline{\mathbf{k}}-\underline{3 \mathbf{m}})$. Compound $\underline{\mathbf{k}}$ appeared to be more sensitive to degradation than $\underline{3 a}$, but the $(E, Z)$ configuration remained unchanged. The reaction conditions were then extended to the formation of $(E, E, Z)$ tertiary trienol $\mathbf{3 n}$, using Methyl (2Z,4E)-5-iodo-3-methylpenta-2,4-dienoate (2) $)$, which was isolated in 56\% yield. 
<smiles>CC(=O)C=C(C)C=CC1(O)C=C(C)CCC1</smiles>

3a, $63 \%^{a}$<smiles>CC(=O)C=C(C)C=CC1(O)CCCCC1</smiles>

3d, $47 \%^{c}$<smiles>CC(=O)C=C(C)C=CC1(O)CCCC1</smiles>

3g, $27 \%^{b, d}$<smiles>CC(=O)C=C(C)C=Cc1ccccc1</smiles>

3j, $78 \%$<smiles>CC(=O)C=C(C)C=CC1(O)C=C(C)CC(C)C1</smiles>

3b, $76 \%^{b}$<smiles>CC(=O)C=C(C)C=CC1(O)CC(C)CC(C)C1</smiles>

3e, $63 \%{ }^{c}$<smiles>CC(=O)C=C(C)C=CC(O)C1CCCCC1</smiles>

3h, $70 \%^{b}$<smiles>CC(=O)C=CC=CC1(O)C=C(C)CCC1</smiles>

3k, $44 \%^{b}$<smiles>CC(=O)C=C(C)C=CC1(O)CCCC=C1C</smiles>

3c, $42 \%^{b}$<smiles>CC(=O)C=C(C)C=CC1(O)CCCC(C)(C)C1</smiles>

3f, $54 \%^{a}$<smiles>CC(=O)C=C(C)C=CC1CCCCC1</smiles>

3i, $42 \%^{b}$<smiles>CC1=CC(O)(/C=C/C(C)=C\C#N)CCC1</smiles>

3l, $49 \%^{b, d}$<smiles>CC1=CC(O)(/C=C/C(C)=C\C(=O)Oc2ccc([N+](=O)[O-])cc2)CCC1</smiles>

$3 \mathrm{~m}, 58 \%$<smiles>CC(=O)C=C(C)C=CC=CC1(O)C=C(C)CCC1</smiles>

$\underline{3 n}, 56 \%^{b}$

Scheme 1. Scope of substrates. ${ }^{a} 1 \mathrm{~h}$ of reaction time. ${ }^{b} 2 \mathrm{~h}$ of reaction time. ${ }^{c} 1 \mathrm{~h} 40 \mathrm{~min}$ was required for the reaction time. ${ }^{d}$ sealed tube. ${ }^{e} 40$ min of reaction time.

\subsection{Synthesis of $A B A$}

Having a method to obtain the diene scaffold in hand, we focused on the synthesis of abscisic acid (ABA). Several syntheses have already been reported in the literature [59-61]. Most of them are based on the introduction of the carbon skeleton of the side chain via the corresponding alkyne in one step [62-65] or with trimethylsilylacetylene $[66,67]$, which is then functionalized by a Sonogashira reaction (Scheme 2). Our strategy requires a reduction step to obtain the final $(E, Z)$ diene fragment. Our approach is based on the introduction of the side chain with our solvent-free Mizoroki-Heck reaction between methyl (2Z)-3-iodobut-2-enoate $\underline{2}$ and $\underline{7}$. Our key cross-coupling precursor was straightforwardly obtained from the commercially available 2,6,6-trimethylcyclohex-2-ene-1,4-dione $\underline{\mathbf{5}}$. 


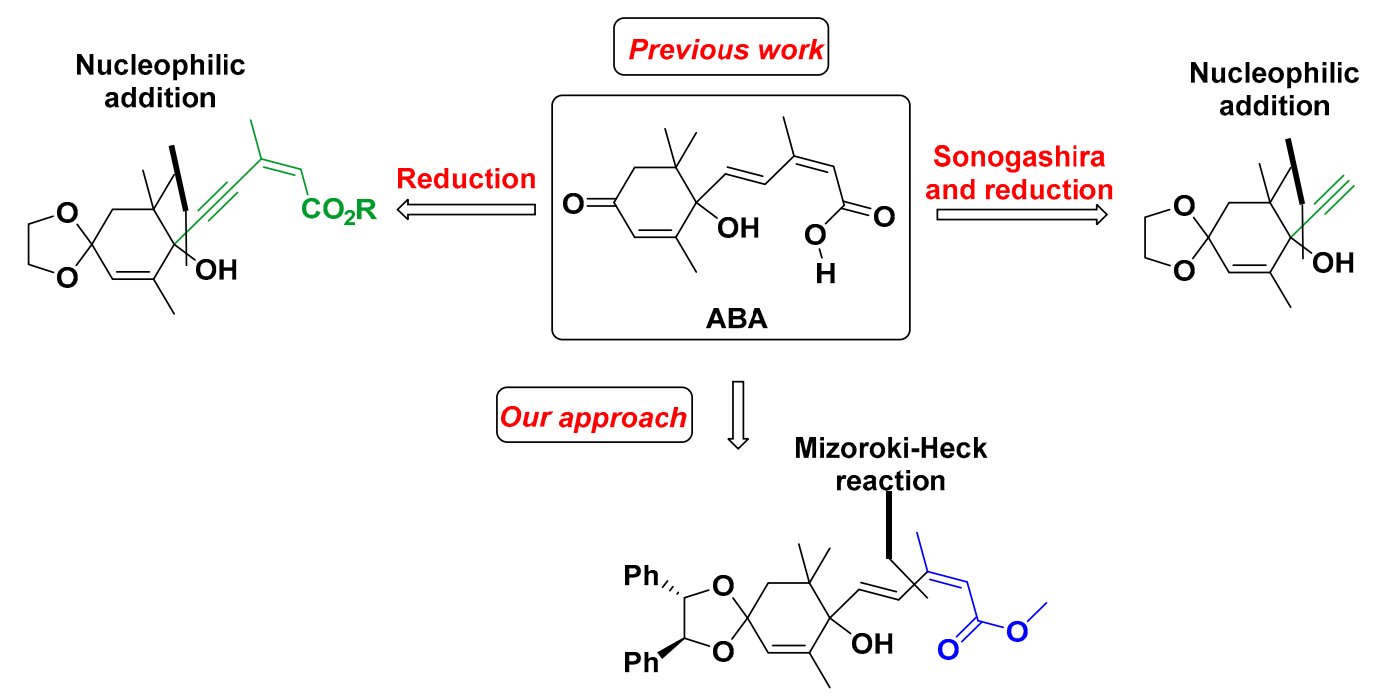

$\underline{7}$

Scheme 2. Retrosynthetic approaches for the synthesis of ABA.

First, the mono protection of the diketone $\underline{\mathbf{5}}$ was tried following the conditions described by Ferrer and co-workers (Scheme 3) [68]. (S,S)-hydrobenzoin, our chiral auxiliary, was heated in presence of a catalytic amount of $p \mathrm{TsOH}$ in benzene. However only the degradation of the hydrobenzoin into benzaldehyde was observed. We then decided to use pyridinium $p$-toluenesulfonate (PPTS), which is a milder acidic catalyst [69].<smiles>CC1=CC(=O)CC(C)(C)C1=O</smiles>

$\underline{5}$<smiles>COC(=O)/C=C(C)\C=C\C1(O)C(C)=CC2(CC(C)(C)C1(C)OC(=O)OC)OC(c1ccccc1)C(c1ccccc1)O2</smiles><smiles>CC1=CC2(CC(C)(C)C1=O)OC(c1ccccc1)C(c1ccccc1)O2</smiles>

$\underline{6}$

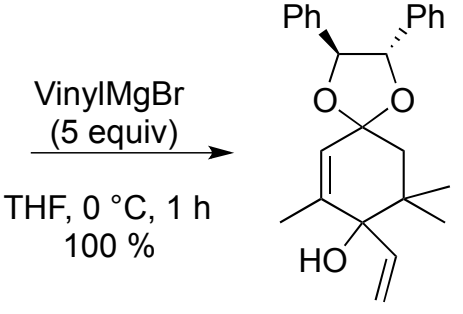

$\underline{7}$

1- $\mathrm{NaOH} 1 \mathrm{~N}, \mathrm{TBACl}$, $\mathrm{THF}, 40^{\circ} \mathrm{C}, 2 \mathrm{~h}$ 2- $\mathrm{HCl} 1 \mathrm{~N}, \mathrm{RT}, 1 \mathrm{~h}$

$59 \%$

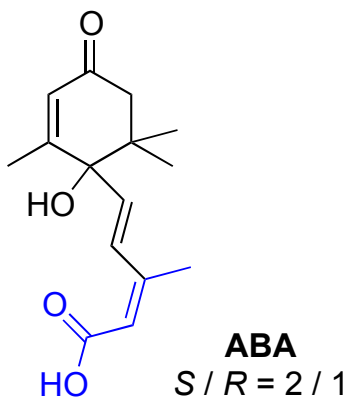

Scheme 3. Synthesis of ABA.

This time, in benzene the desired product $\underline{6}$ was isolated after 5 days in a promising $24 \%$ yield. A survey of different solvents was made and fortunately, the environmentally sound cyclohexane significantly improved the yield and the reaction time since $\underline{\mathbf{6}}$ was obtained in $96 \%$ yield after $18 \mathrm{~h}$. Next, the Grignard reaction with an excess of vinylmagnesium bromide gave quantitatively $\underline{\mathbf{Z}}$ as a 
mixture of inseparable diastereoisomers. The $R / S$ ratio of the newly formed center was determined by HPLC. Disappointingly, working at a lower temperature $\left(-20^{\circ} \mathrm{C}\right.$ or $\left.-78^{\circ} \mathrm{C}\right)$ did not improve this ratio much while it considerably reduced the formation of $\underline{7}$. Nevertheless, our key step was performed on the mixture of both isomers and the expected (E/Z)-diene $\underline{8}$ was isolated in $96 \%$ yield without racemization, the $R / S$ ratio remained unchanged during the formation of the diene $\underline{8}$. A saponification followed by an acidic treatment enabled the formation of abscisic acid with the same $R / S$ ration and therefore enantiomerically enriched in its $S$ isomer. The final product was synthetized in four steps from $\underline{\mathbf{5}}$ in $54 \%$ global yields.

\section{Conclusions}

To conclude, we managed to develop an efficient, environmentally sound method to synthetize delicate dienes and trienes via a Mizoroki-Heck reaction. The configuration of the double bonds was controlled, and no isomerization was observed. The salient features of our approach are the association of simple terminal olefins with various vinylic iodides, palladium acetate under air without any ligand or solvent. Our optimized solvent-free Mizoroki-Heck reaction was next successfully applied to the synthesis of ABA. This method offers a short new pathway where solvents and reagents were chosen to give an environmentally friendlier alternative to the synthesis already available in the literature.

Supplementary Materials: The following are available online at http:/ /www.mdpi.com/2073-4344/8/3/115/s1, Figure S1: ${ }^{1} \mathrm{H}$ NMR and ${ }^{13} \mathrm{C}$ NMR Spectra of all compounds.

Acknowledgments: We acknowledge the Region Centre for financial support.

Author Contributions: Sabine Berteina-Raboin conceived and designed the experiments. Geoffrey Dumonteil performed the experiments. Geoffrey Dumonteil, Marie-Aude Hiebel and Sabine Berteina-Raboin analyzed the data and wrote the paper.

Conflicts of Interest: The authors declare no conflict of interest.

\section{References}

1. Hopf, H.; Maas, G. Synthesis and Transformation of Radialenes. In The Chemistry of Dienes and Polyenes, Vol. 1; Rappoport, Z., Ed.; Wiley: Chichester, UK, 1997; ISBN 978-0-471-96512-1.

2. De Paolis, M.; Chataigner, I.; Maddaluno, J. Recent advances in stereoselective synthesis of 1,3-dienes. Top. Curr. Chem. 2012, 327, 87-146. [CrossRef]

3. Takeda, T. (Ed.) Modern Carbonyl Olefination: Methods and Applications; Wiley-VCH: Weinheim, Germany, 2004; ISBN 978-3-527-60538-5.

4. Grubbs, R.H. (Ed.) Handbook of Metathesis, Vol. 1; Wiley-VCH: Weinheim, Germany, 2003; ISBN 978-3-527-30616-9.

5. Van Horn, D.E.; Negishi, E. Selective carbon-carbon bond formation via transition metal catalysts. 8 . Controlled carbometalation. Reaction of acetylenes with organoalane-zirconocene dichloride complexes as a route to stereo- and regio-defined trisubstituted olefins. J. Am. Chem. Soc. 1978, 100, 2252-2254. [CrossRef]

6. Negishi, E. Bimetallic catalytic systems containing $\mathrm{Ti}, \mathrm{Zr}, \mathrm{Ni}$, and $\mathrm{Pd}$. Their applications to selective organic syntheses. Pure Appl. Chem. 1981, 53, 2333-2356. [CrossRef]

7. Negishi, E.; Van Horn, D.E.; Yoshida, T. Controlled carbometalation. 20. Carbometalation reaction of alkynes with organoalene-zirconocene derivatives as a route to stereo-and regiodefined trisubstituted alkenes. J. Am. Chem. Soc. 1985, 107, 6639-6647. [CrossRef]

8. Robinson, C.Y.; Brouilllette, W.J.; Muccio, D.D. Reactions of vinylogous phosphonate carbanions and Reformatskii reagents with a sterically hindered ketone and enone. J. Org. Chem. 1989, 54, 1992-1997. [CrossRef]

9. Horie, H.; Kurahashi, T.; Matsubara, S. Selective synthesis of trienes and dienes via nickel-catalyzed intermolecular cotrimerization of acrylates and alkynes. Chem. Commun. 2010, 46, 7229-7231. [CrossRef] [PubMed] 
10. Negishi, E.; Okukado, N.; King, A.O.; Van Horn, D.E.; Spiegel, B.I. Selective carbon-carbon bond formation via transition metal catalysts. 9. Double metal catalysis in the cross-coupling reaction and its application to the stereo- and regioselective synthesis of trisubstituted olefins. J. Am. Chem. Soc. 1978, 100, 2254-2256. [CrossRef]

11. Negishi, E.; Hu, Q.; Wang, Z.; Yin, N. The Chemistry of Organozinc Compounds; Rappoport, Z., Marek, I., Eds.; John Wiley \& Sons, Ltd.: Chichester, UK, 2006; Chapter 11; p. 453, ISBN 978-0-470-09339-9.

12. Stille, J.K.; Milstein, D. A general, selective, and facile method for ketone synthesis from acid chlorides and organotin compounds catalyzed by palladium. J. Am. Chem. Soc. 1978, 100, 3636-6638. [CrossRef]

13. Stille, J.K. The Palladium-Catalyzed Cross-Coupling Reactions of Organotin Reagents with Organic Electrophiles. Angew. Chem. Int. Ed. Engl. 1986, 25, 508-524. [CrossRef]

14. Farina, V. New perspectives in the cross-coupling reactions of organostannanes. Pure Appl. Chem. 1996, 68, 73-78. [CrossRef]

15. Farina, V.; Krishnamurthy, V.; Scott, W.J. The Stille Reaction. Org. React. 1997, 50. [CrossRef]

16. Miyaura, N.; Suzuki, A. Palladium-Catalyzed Cross-Coupling Reactions of Organoboron Compounds. Chem. Rev. 1995, 95, 2457-2483. [CrossRef]

17. Stanforth, S.P. Catalytic cross-coupling reactions in biaryl synthesis. Tetrahedron 1998, 54, 263-303. [CrossRef]

18. Suzuki, A. Recent advances in the cross-coupling reactions of organoboron derivatives with organic electrophiles 1995-1998. J. Organomet. Chem. 1999, 576, 147-168. [CrossRef]

19. Kotovshchikov, Y.N.; Latyshev, G.V.; Lukashev, N.V.; Beletskaya, I.P. Alkynylation of steroids via Pd-free Sonogashira coupling. Org. Biomol. Chem. 2015, 13, 5542-5555. [CrossRef] [PubMed]

20. Murahashi, S.-I. Palladium-catalyzed cross-coupling reaction of organic halides with Grignard reagents, organolithium compounds and heteroatom nucleophiles. J. Organomet. Chem. 2002, 653, 27-33. [CrossRef]

21. Dounay, A.B.; Overman, L.E. The Asymmetric Intramolecular Heck Reaction in Natural Product Total Synthesis. Chem. Rev. 2003, 103, 2945-2964. [CrossRef] [PubMed]

22. Bräse, S.; De Meijeren, F. Metal-Catalyzed Cross-Coupling Reactions; De Meijere, A., Diederich, F., Eds.; Wiley-VCH: New York, NY, USA, 2004; Chapter 5, ISBN 978-3-527-61953-5.

23. Fayol, A.; Fang, Y.-Q.; Lautens, M. Synthesis of 2-Vinylic Indoles and Derivatives via a Pd-Catalyzed Tandem Coupling Reaction. Org. Lett. 2006, 8, 4203-4206. [CrossRef] [PubMed]

24. Battace, A.; Zair, T.; Doucet, H.; Santelli, M. Heck Vinylations Using Vinyl Sulfide, Vinyl Sulfoxide, Vinyl Sulfone, or Vinyl Sulfonate Derivatives and Aryl Bromides Catalyzed by a Palladium Complex Derived from a Tetraphosphine. Synthesis 2006, 20, 3495-3505. [CrossRef]

25. McConville, M.; Saidi, O.; Blacker, J.; Xiao, J. Regioselective Heck Vinylation of Electron-Rich Olefins with Vinyl Halides: Is the Neutral Pathway in Operation? J. Org. Chem. 2009, 74, 2692-2698. [CrossRef] [PubMed]

26. Hartwig, J.F. Handbook of Organopalladium Chemistry for Organic Synthesis; Negishi, E., Ed.; Wiley: Chichester, UK, 2002; ISBN 978-0-47-121246-1.

27. Beletskaya, I.P.; Cheprakov, A.V. Comprehensive Coordination Chemistry II; McCleverty, J.A., Meyer, T.J., Eds.; Wiley-VCH: Weinheim, UK, 2004; ISBN 978-0-080-91316-2.

28. Wang, K.; Chen, S.; Zhang, H.; Xu, S.; Ye, F.; Zhanga, Y.; Wang, J. Pd(0)-catalyzed cross-coupling of allyl halides with $\alpha$-diazocarbonyl compounds or $N$-mesylhydrazones: Synthesis of 1,3-diene compounds. Org. Biomol. Chem. 2016, 14, 3809-3820. [CrossRef] [PubMed]

29. O'Nei, G.W.; Phillips, A.J. Total Synthesis of (-)-Dictyostatin. J. Am. Chem. Soc. 2006, 128, 5340-5341. [CrossRef] [PubMed]

30. Negishi, E.; Wang, G.; Rao, H.; Xu, Z. Alkyne Elementometalation-Pd-Catalyzed Cross-Coupling. Toward Synthesis of All Conceivable Types of Acyclic Alkenes in High Yields, Efficiently, Selectively, Economically, and Safely: “Green" Way. J. Org. Chem. 2010, 75, 3151-3182. [CrossRef] [PubMed]

31. Eto, K.; Yoshino, M.; Takahashi, K.; Ishihara, J.; Hatakeyama, S. Total Synthesis of Oxazolomycin A. Org. Lett. 2011, 13, 5398-5401. [CrossRef] [PubMed]

32. Schmidt, B.; Kunz, O. One-Flask Tethered Ring Closing Metathesis-Electrocyclic Ring Opening for the Highly Stereoselective Synthesis of Conjugated Z/E-Dienes. Eur. J. Org. Chem. 2012, 5, 1008-1018. [CrossRef]

33. Souris, C.; Frébault, F.; Patel, A.; Audisio, D.; Houk, K.N.; Maulide, N. Stereoselective Synthesis of Dienyl-Carboxylate Building Blocks: Formal Synthesis of Inthomycin C. Org. Lett. 2013, 15, 3242-3245. [CrossRef] [PubMed] 
34. Hiebel, M.-A.; Fall, Y.; Scherrmann, M.-C.; Berteina-Raboin, S. Straightforward Synthesis of Various 2,3-Diarylimidazo[1,2-a]pyridines in PEG400 Medium through One-Pot Condensation and C-H Arylation. Eur. J. Org. Chem. 2014, 21, 4643-4650. [CrossRef]

35. Hiebel, M.-A.; Berteina-Raboin, S. Iodine-catalyzed regioselective sulfenylation of imidazoheterocycles in PEG400. Green Chem. 2015, 17, 937-944. [CrossRef]

36. Tber, Z.; Hiebel, M.-A.; Akssira, M.; Guillaumet, G.; Berteina-Raboin, S. Use of Ligand-Free Iron/Copper Cocatalyst for Nitrogen and Sulfur Cross-Coupling Reaction with 6-Iodoimidazo[1,2-a]pyridine. Synthesis 2015, 47, 1780-1790. [CrossRef]

37. Addicott, F.T.; Carns, H.R. Abscisic Acids; Addicott, F.T., Ed.; Praeger: New York, NY, USA, 1983 ; Chapter 1.

38. Finkelstein, R.F.; Tenbarge, K.M.; Shumway, J.E.; Crunch, M.L. Role of ABA in Maturation of Rapeseed Embryos. Plant Physiol. 1985, 78, 630-636. [CrossRef] [PubMed]

39. Léon-Kloosterziel, K.M.; Van de Bunt, G.A.; Zeevaart, J.A.D.; Koornneef, M. Arabidopsis Mutants with a Reduced Seed Dormancy. Plant Physiol. 1996, 110, 233-240. [CrossRef] [PubMed]

40. Shinozaki, K.; Yamaguchi-Shinozaki, K. Molecular responses to dehydration and low temperature: Differences and cross-talk between two stress signaling pathways. Curr. Opin. Plant. Biol. 2000, 3, 217-223. [CrossRef]

41. Himmelbach, A.; Yang, Y.; Grill, E. Relay and control of abscisic acid signaling. Curr. Opin. Plant. Biol. 2003, 6, 470-479. [CrossRef]

42. Nambara, E.; Marion-Poll, A. Abscisic acid biosynthesis and catabolism. Annu. Rev. Plant. Biol. 2005, 56, 165-186. [CrossRef] [PubMed]

43. Todoroki, Y.; Narita, K.; Muramatsu, T.; Shimamura, H.; Ohnishi, T.; Mizutani, M.; Ueno, K.; Hirai, N. Synthesis and biological activity of amino acid conjugates of abscisic acid. Bioorg. Med. Chem. 2011, 19, 1743-1750. [CrossRef] [PubMed]

44. Guri, A.J.; Hontecillas, R.; Si, H.; Liu, D.; Bassaganya-Riera, J. Dietary abscisic acid ameliorates glucose tolerance and obesity-related inflammation in $\mathrm{db} / \mathrm{db}$ mice fed high-fat diets. Clin. Nutr. 2007, 26, 107-116. [CrossRef] [PubMed]

45. Bellotti, M.; Salis, A.; Grozio, A.; Damonte, G.; Vigliarolo, T.; Galatini, A.; Zocchi, E.; Benatti, U.; Millo, E. Synthesis, structural characterization and effect on human granulocyte intracellular cAMP levels of abscisic acid analogs. Bioorg. Med. Chem. 2015, 23, 22-32. [CrossRef] [PubMed]

46. Brandt, D.; Bellosta, V.; Cossy, J. Stereoselective Synthesis of Conjugated Trienols from Allylic Alcohols and 1-Iodo-1,3-dienes. Org. Lett. 2012, 14, 5594-5597. [CrossRef] [PubMed]

47. McCubbin, J.A.; Voth, S.; Krokhin, O.V. Mild and Tunable Benzoic Acid Catalysts for Rearrangement Reactions of Allylic Alcohols. J. Org. Chem. 2011, 76, 8537-8542. [CrossRef] [PubMed]

48. Li, P.-F.; Wang, H.-L.; Qu, J. 1,n-Rearrangement of Allylic Alcohols Promoted by Hot Water: Application to the Synthesis of Navenone B, a Polyene Natural Product. J. Org. Chem. 2014, 79, 3955-3962. [CrossRef] [PubMed]

49. Knowles, J.P.; O'Connor, V.E.; Whiting, A. Studies towards the synthesis of the northern polyene of viridenomycin and synthesis of Z-double bond analogues. Org. Biomol. Chem. 2011, 9, 1876-1886. [CrossRef] [PubMed]

50. Diaz-Ortiz, A.; Prieto, P.; Vazquez, E. Heck Reactions under Microwave Irradiation in Solvent-Free Conditions. Synlett 1997, 3, 269-270. [CrossRef]

51. Leadbeater, N.E.; Williams, V.A.; Barnard, T.M.; Collins, M.J., Jr. Solvent-Free, Open-Vessel Microwave-Promoted Heck Couplings: From the mmol to the mol Scale. Synlett 2006, 18, 2953-2958. [CrossRef]

52. Du, L.-H.; Wang, Y.-G. Microwave-Promoted Heck Reaction Using $\mathrm{Pd}(\mathrm{OAc})_{2}$ as Catalyst under Ligand-Free and Solvent-Free Conditions. Synth. Commun. 2007, 37, 217-222. [CrossRef]

53. Liu, G.; Hou, M.; Song, J.; Jiang, T.; Fan, H.; Zhang, Z.; Han, B. Immobilization of Pd nanoparticles with functional ionic liquid grafted onto cross-linked polymer for solvent-free Heck reaction. Green Chem. 2010, 12, 65-69. [CrossRef]

54. Firouzabadi, H.; Iranpoor, N.; Kazemi, F.; Gholinejad, M. Palladium nano-particles supported on agarose as efficient catalyst and bioorganic ligand for CC bond formation via solventless Mizoroki-Heck reaction and Sonogashira-Hagihara reaction in polyethylene glycol (PEG 400). J. Mol. Catal. A Chem. 2012, 357, 154-161. [CrossRef] 
55. Khazaei, A.; Rahmati, S.; Hekmatian, Z.; Saeednia, S. A green approach for the synthesis of palladium nanoparticles supported on pectin: Application as a catalyst for solvent-free Mizoroki-Heck reaction. J. Mol. Catal. A Chem. 2013, 372, 160-166. [CrossRef]

56. Zolfigol, M.A.; Azadbakht, T.; Khakyzadeh, V.; Nejatyami, R.; Perrin, D.M. C(sp2)-C(sp2) cross coupling reactions catalyzed by an active and highly stable magnetically separable Pd-nanocatalyst in aqueous media. RSC Adv. 2014, 4, 40036-40042. [CrossRef]

57. Khazaei, A.; Khazaei, M.; Rahmati, S. A green method for the synthesis of gelatin/pectin stabilized palladium nano-particles as efficient heterogeneous catalyst for solvent-free Mizoroki-Heck reaction. J. Mol. Catal. A Chem. 2015, 398, 241-247. [CrossRef]

58. Trost, B.M.; Conway, W.P.; Strege, P.E.; Dietsche, T.J. New Synthetic reactions. Alkylative elimination. J. Am. Chem. Soc. 1974, 96, 7165-7167. [CrossRef]

59. Roberts, D.L.; Heckmann, R.A.; Hege, B.P.; Bellin, S.A. Synthesis of (RS)-abscisic acid. J. Org. Chem. 1968, 33, 3566-3569. [CrossRef]

60. Constantino, M.G.; Losco, P. A novel synthesis of ( \pm )-abscisic acid. J. Org. Chem. 1989, 54, 681-683. [CrossRef]

61. Cornforth, J.; Hawes, J.E.; Mallaby, R. A Stereospecific Synthesis of ( \pm )-Abscisic Acid. Aust. J. Chem. 1992, 45, 179-185. [CrossRef]

62. Mayer, H.J.; Rigassi, N.; Schwieter, U.; Weedon, B.C.L. Synthesis of Abscisic Acid. Helv. Chim. Acta 1976, 59, 1424-1427. [CrossRef]

63. Kienzle, F.; Mayer, H.; Minder, R.E.; Thommen, H. Synthese von optisch aktiven, natürlichen Carotinoiden und strukturell verwandten Verbindungen. III. Synthese von (+)-Abscisinsäure, (-)-Xanthoxin, (-)-Loliolid, (-)-Actinidiolid und (-)-Dihydroactinidiolid. Helv. Chim. Acta 1978, 61, 2616-2627. [CrossRef]

64. Constantino, M.G.; Donate, P.M.; Petragnani, N. An efficient synthesis of ( \pm )-abscisic acid. J. Org. Chem. 1986, 51, 253-254. [CrossRef]

65. Rose, P.A.; Abrams, S.R.; Shaw, A.C. Synthesis of chiral acetylenic analogs of the plant hormone abscisic acid. Tetrahedron Asymmetry 1992, 3, 443-450. [CrossRef]

66. Hanson, J.R.; Uyanik, C. An efficient synthesis of the plant hormone abscisic acid. J. Chem. Res. 2003, 7, 426-427. [CrossRef]

67. Smith, T.R.; Clark, A.J.; Clarkson, G.J.; Taylor, P.C.; Marsh, A. Concise enantioselective synthesis of abscisic acid and a new analogue. Org. Biomol. Chem. 2006, 4, 4186-4192. [CrossRef] [PubMed]

68. Ferrer, E.; Alibés, R.; Busqué, F.; Figueredo, M.; Font, J.; De March, P. Enantiodivergent Synthesis of Cyclohexenyl Nucleosides. J. Org. Chem. 2009, 74, 2425-2432. [CrossRef] [PubMed]

69. Mash, E.A.; Torok, D.S. Homochiral ketals in organic synthesis. Diastereoselective cyclopropanation of alpha beta-unsaturated ketals derived from (S,S)-(-)-hydrobenzoin. J. Org. Chem. 1989, 54, 250-253. [CrossRef] 